\title{
Peningkatan Fungsi Kognitif Klien dengan Isolasi Sosial yang Mendapatkan Latihan Keterampilan Sosial: Literature Review
}

\author{
Suyatno' $^{1}$, Achir Yani S. Hamid ${ }^{2}$
}

1. Mahasiswa Program Magister Fakultas Ilmu Keperawatan, Universitas Indonesia 2. Departemen Keperawatan Jiwa, Fakultas Ilmu Keperawatan, Universitas Indonesia

Email: yatnoibad@gmail.com

\begin{abstract}
Abstrak
Latihan Keterampilan Sosial (LKS) merupakan salah satu intervensi yang ditujukan untuk meningkatkan komunikasi dan memberikan keterampilan baru pada klien skizofrenia dengan masalah isolasi sosial. LKS secara khusus dilakukan terhadap Klien dengan isolasi sosial yang mengalami penurunan jumlah, frekuensi, dan kualitas kontak sosial; daya tahan kontak dan negativisme yang dikaitkan dengan perasaan terisolasi individu. LKS diberikan melalui beberapa sesi. Setiap sesi meliputi beberapa bagian yaitumodelling, role playing, performance feedback dan transfer training. Tahapan dalam LKS tersebut tidak hanya berfokus pada keterampilan sosial, akan tetapi juga fungsi kognitif. LKS dapat dilakukan pada semua klien baik sehat maupun gangguan dan untuk anak-anak maupun dewasa. Metode: Literature review dilakukan berdasarkan issue, metodologi, persamaan dan proposal penelitian lanjutan. Terdapat 5 penelitian yang bersifat kuantitatif dan 1 buletin. LimaPenelitian dilakukan padasatu orang klien sehat dan 4 orang klien sakit seperti pada autism, risiko tinggi, dan gangguan kognitif.Dari hasil penelitian dan bulletin didapatkan bahwa LKS dapat dilakukan selain pada skizofrenia juga pada klien yang sehat dan autism.
\end{abstract}

Kata kunci: Latihan Keterampilan Sosial, Fungsi Kognitif, Skizofrenia

\section{Enhancing the Cognitive Function of Clients with Social Isolation Getting Social Skills Training: Literature Review}

\begin{abstract}
Social Skills Training (SST) is one of the interventions aimed at improving communication and providing new skills to schizophrenic clients with social isolation problems. SST is specifically carried out on clients with social isolation experiencing a decrease number, frequency and quality of social contacts; endurance of contact and negativism are associated with feelings of isolated.SST is performedthrough several sessions. Each session consisted of several sections such as modeling, role playing, performance feedback and transfer training. The stages in the SST not only focus on social skills, but also cognitive functions. SST can be applied tohealthy and disturbed clients, children as well as adults. Method: Literature review is based on issues, methodologies, equations and advanced research proposals. There are 5 quantitative studies and 1 bulletin. Out of Five studies conducted, one study on healthy clients and 4 disturbed clients.such as autism, high risk, and cognitive impairment.
\end{abstract}

Keywords: Social Skills Training, Cognitive Functions, Schizophrenia 


\section{Pendahuluan}

Klien skizofrenia dengan masalah perilaku isolasi sosial umumnya mengalami halusinasi dan defisit kognitif (Bhatti \& Haq, 2017). Fungsi kognitif berfungsi untuk penyimpanan, transformasi dan penggunaan pengetahuan (Matlin, 2003; Reed, 2012). Pada laporan kasus klien dengan isolasi sosial terdapat gangguan pada berbagai macam proses mental seperti perhatian, pembelajaran, memori, bahasa, persepsi dan fungsi khusus (misalnya, penalaran, pengambilan keputusan, perencanaan dan penetapan tujuan) (Jurado \& Rosselli, 2007). Proses mental ini disebut fungsi kognitif yang diperlukan untuk hidup kemandirian dalam kehidupan sehari-hari. Kemampuan kognitif yang memadai tergantung pada fungsi kognitif yang menjadi dasar kinerja dalam semua tugas sehari-hari (Bosworth \& Ayotte, 2009). Fungsi kognitif yang menurun secara signifikan mengurangi kualitas kehidupan individu dan kesulitan dalam mempertahankan hubungan sosial. Penelitian lain juga menyebutkan bahwa isolasi sosial dapat mengakibatkan penurunan fungsi kognitif dan meningkatkan risiko terjadinya Alzheimer serta meningkatkan keparahan klien skizofrenia dengan isolasi sosial. Penurunan kognitif ini dapat terjadi karena adanya gangguan yang dihasilkan dari kurangnya dukungan sosial pada lapisan organisasi dan keluarga (Bhatti \& Haq, 2017; Manoach, 2010).Beberapa penelitian telah mempelajari tentang hubungan antara kurangnya hubungan sosial dapat mendukung terjadinya penurunan fungsi kognitif. Penelitian tersebut melihat dari segi struktur, fungsional dan gabungan dari kurangnya hubungan sosial. Secara jelas belum bisa disimpulkan tentang hubungan keduanya, akan tetapi hasil dari penelitian menjelaskan tentang berkurangnya fungsi kognitif dengan kurangnya hubungan sosial.

Pada umumnya, isolasi sosial ditinjau dari aspekjumlah, frekuensi, dan kualitas kontak; daya tahan kontak dan negativisme yang dikaitkan dengan perasaan terisolasi yang dialami individu.(Biordi \& Nicholson, 2013). Isolasi sosial merupakan masalah psikososial yang penting untuk ditangani. Isolasi sosial dapat menyebabkan gangguan fisik seperti pada kesehatan jantung, merusak self esteem, depresi dan bahkan bunuh diri (WHO, 2014; Rahmani, 2014). Isolasi sosial dapat memperpanjang hospitalisasi, pengabaian kebutuhan dasar klien dan memunculkan masalah baru yaitu halusinasi, dimana hal tersebut dapat membahayakan atau merugikan diri sendiri, orang sekitar dan lingkungan. Halusinasi dapat terjadi sebagai usaha untuk mendapatkan kebutuhan (hubungan komunikasi, kontrol diri dan pengakuan) yang mana hal tersebut tidak didapatkan di dunia nyata. Halusinasi sebagai bentuk pengganti dari hubungan antar manusia yang tak diperoleh lagi, sehingga orang yang menarik diri lingkungan (isolasi diri) cenderung untuk mengalami halusinasi (Stuart and Sundeen, 2006 dalam Jallo, 2008). 
Selain halusinasi, isolasi juga dapat mempengaruhi kognitif klien. (Bhatti \& Haq, 2017).Salah satu teori yang dapat menjelaskan bahwa kurangnya hubungan sosial dapat menimbulkan berkurangnya fungsi kognitif yaitu teori "gunakan ini atau akan kehilangannya" (Hultsch et al, 1999). Teori ini dapat digambarkan otak sebagai otot dan hubungan intelektual, sosial dan aktivitas fisik dapat menstimulasi otak. Hubungan sosial yang kurang dalam aktivitas sehari-hari dapat mengakibatkan tidak digunakannya otak, sehingga dapat menimbulkan berkurangnya fungsi otak. Tindakan keperawatan yang dilakukan pada klien dengan isolasi sosial adalah latihan Social Skill Training (SST), CognitiveBehavioral Therapy (CBT), shyness Groups (Peplau dan Pearlman, 1982). Terapi-terapi keperawatan yang terintegrasi dengan tindakan profesi kesehatan lain yang menangani isolasi sosial antara lainpsikiater, psikolog, pekerja sosial. Terapi medis berupa terapi psikofarmaka (Videbeck, 2008; Varcarolis, Carson \& Shoemaker 2006, Frisch \& Frisch, 2006 ; Brady, 2004), sedangkan terapi keperawatan berupa terapi standar (generalis) dan terapi psikososial atau psikoterapi (spesialis). Terapi standar (generalis) bertujuan untuk melatih ketrampilan sosialklien sehingga klien merasa nyaman dalam situasi sosial dan melakukan interaksi sosial (Swanson, dkk, 2008, Workshop Keperawatan Jiwa, 2008 ; Frisch \& Frisch, 2006). Terapi-terapi tersebut yang sudah memberikan dampak yang signifikan yaitu LKS, seperti halnya dibuktikan dengan penelitian Tobing
(2017) yang menunjukkan peningkatan kemampuan sosialisasi secara bermakna.

Latihan Keterampilan Sosial (LKS) merupakan salah satu intervensi dengan teknik modifikasi perilaku berdasarkan prinsip-prinsip bermain peran, praktik dan umpan balik guna peningkatkan kemampuan klien dalam menyelesaikan masalah pada klien depresi, skizofrenia, klien dengan gangguan perilaku kesulitan berinteraksi, mengalami fobia sosial dan klien yang mengalami kecemasan (Kneisl 2004; Stuart 2013; Varcarolis ,2006).

LKS ditujukan untuk meningkatkan kemampuan berkomunikasi dan keterampilan sosial bagi seseorang yang mengalami kesulitan dalam berinteraksi meliputi keterampilan memberikan pujian, mengeluh karena tidak setuju, menolak permintaan orang lain, tukar menukar pengalaman, menuntut hak pribadi, memberi saran pada orang lain, pemecahan masalah yang dihadapi dan bekerjasama dengan orang lain.Kemampuan tersebut perlu dikembalikan pada klien dengan isolasi sosial. Isolasi sosial merupakan suatu keadaan yang menggambarkan keterpisahan seseorang dari orang terdekat, kelompok, aktivitas dan keadaan sosial yang dapat mengganggu proses sosial seseorang (Sells, 2008).

Penatalaksanaan yang dapat digunakan pada klien dengan isolasi sosial yaitu dengan penatalaksanaanklien dengan melatihnya bersosialisasi dengan orang lain. Terapi tersebut yaitu Latihan Keterampilan Sosial (LKS). LKS merupakan terapi yang berfokus pada tugas dan untuk membentuk perilaku yang baru. LKS dapat digunakan dalam meningkatkan dan membentuk komunikasi yang fleksibel sehingga klien 
mampu menanggapi respons dengan baik terhadap situasi yang beraneka ragam. Selain itu, penelitian dari Renidayati, Keliat dan Sabri (2008) menyimpulkan bahwa kemampuan kognitif dan juga kemampuan perilaku pada klien lebih tinggi pada kelompok yang mengikuti Latihan Keterampilan Sosial, sehingga terapi tersebut direkomendasikan sebagai terapi keperawatan klien yang mengalami isolasi sosial dengan gangguan fungsi kognitif (Azizah, Hamid, \& Wardani, 2017).

Manfaat dari LKS dari segi kognitif yaitu adanya pembelajaran aktif atau keterampilan pemecahan masalah sosial (Kopelowicz, Liberman, \& Zarate, 2006). Aktif dalam bekerja atau menggunakan pola pikir untuk menyelesaikan masalah yang dihadapi dapat menstimulus otak untuk bekerja sehingga fungsi otak tetap terjaga. Ketika seseorang dibekali dengan keterampilan untuk mengatasi masalah kehidupan sehari-hari yang penuh dengan tekanan, maka mereka akan mahir dalam memecahkan masalah dan tantangan yang dihadapidalamkehidupan, sehingga stresor menjadi berkurang dan fungsi sosial pun tetap terjaga.

Fungsi sosial klien meningkat setelah dilakukan perawatan dengan psikofarmaka dan menekankan pada aspek psikososial melalui intervensi keluarga, pelatihan keterampilan sosial. Kondisi peningkatan kemampuan ini akan berdampak positif pada kualitas kehidupan klien yang lebih baik (Arsova, Bajraktarov, Barbov \& Hadzihamza, 2014).

\section{Bahan dan Metode}

Jurnal yang digunakan dalam literature review didapatkan melalui database penyedia jurnal international Sciencedirect, Proquest dan jurnal yang telah bekerja dengan perpustakaan Universitas Indonesia. Penulis menuliskan kata kunci sesuai MESH (Medical Subject Heading) yaitu "social skill training" dan "cognitive" dan dipilih full text didapatkan 2,203 temuan, kemudian dipersempit dengan yang dissertation and theses dan ditemukan 1,600 temuan.Selanjutnya diurutkan dari lima tahun terakhir didapatkan 158 temuan. Hal lain yang relevan dimana setiap pertanyaan tersebut telah mengikuti PICOT dimana setiap pertanyaan .terdapat $\mathrm{P}=$ problem/ pasien/ populasi, $\mathrm{I} / \mathrm{E}=$ implementasi/intervensi/exposure, $\mathrm{C}=$ kontrol/ intervensi pembanding, $\mathrm{O}=$ hasil dan $\mathrm{T}=$ Time.yang penulis gunakan dalam mendapatkan jurnal dan artikel tentang fungsi kognitif pada latihan keterampilan sosial.

\section{Hasil}

Pemberian Latihan Keterampilan Sosial (LKS) dapat memberikan dampak pada fungsi kognitif. LKS pada tujuan utamanya yaitu untuk memberikan latihan pada klien skizofrenia dengan isolasi sosial untuk dapat berinteraksi dengan orang lain, memiliki sahabat dan berkelompok. LKS juga dapat digunakan pada berbagai klien selain pada skizofrenia yaitu seperti pada klien dengan autis dan pada remaja dengan gangguan kognitif. LKS dapat memberikan keterampilan baru yang bertujuan untuk kemandirian klien tersebut. Keterampilan dapat diberikan melalui modelling, role play, feed back dan transfer training kepada klien. Keterampilan baru yang telah diperoleh merupakan rangkaian proses yang terjadi di kognitif atau otak. Dengan demikian maka segi kognitif ikut terpengaruh dalam kegiatan LKS.

\section{Pembahasan}

Teori Piaget (tahun, 1983) biasa disebut dengan genetic epistimologi 
(epistimologi genetik) karena dalam teori ini berusaha melacak perkembangan dari kemampuan intelektual, bahwa genetikmengacu pada pertumbuhan perkembangan dan bukan warisan biologis (keturunan) (Hergenhahn \& Matthew, 2010).Piaget menyatakan bahwa anak yang dilahirkan memiliki skemata sensorimotor yang memberikan arah atau bentuk dalam interaksi awal terhadap lingkungan. Peristiwa atau kejadian yang dialami anak pada masa awal diasimilasikan ke dalam bentuk skemata yang bisa direspons oleh anak. Maka dari itu, peristiwa tersebut menentukan kemampuan pengalaman responsanak. Melalui pengalaman, skema tersebut dapat diubah atau dimodifikasi. Setiap pengalaman yang diperoleh mengandung elemen unik yang harus diakomodasi oleh struktur kognitif anak. Struktur kognitif bisa berubah dan memungkinkan perkembangan pengalaman secara terus-menerus melalui interaksi terhadap lingkungan.

Menurut Piaget perkembangan intelektual didasarkan pada 2 fungsi yaitu organisme dan adaptasi ( Ratna, 2011). Fungsi organisme ditujukan untuk membuat proses fisik atau psikologi menjadi sistem yang dapat berhubungan dan teratur, seperti bayi yang memiliki kemampuan untuk memfokuskan pandangan dan memegang sesuatu secara terpisah. Pada perkembangan selanjutnya, bayi dapat mengatur atau mengorganisir kedua struktur perilaku menjadi yang lebih tinggi.Piaget menyatakan bahwa perkembangan intelektual adalah proses untuk membentuk model realitas dalam diri untuk memperoleh informasi mengenai berbagai gambaran bentuk dunia luar, sebagian besar masa kecil untuk mempelajari dirinya sendiri dan dunia luar (Ratna, 2011).

Adaptasi merupakan fungsi kedua yang mendasari perkembangan intelektual.
Fungsi pertama sebagai proses penyesuaian skema dalam merespons lingkungan melalui proses yang tidak dipisahkan, yaitu: asimilasimerupakan penyatuan (pengintegrasian) informasi, konsep, persepsi, dan pengalaman baru kedalam pikiran seseorang (Wina, 2010). Pada Proses tersebut seseorang menggunakan struktur atau kemampuan yang sudah didapat dalam menghadapi masalahnya (Ratna, 2011).Fungsikedua merupakan akomodasi yaitu individu yang mengubah dirinya agar bersesuaian dengan sesuatu yang diterima dari lingkungannya (Surya, 2003). Sebagai proses penyesuaian atau penyusunan ke dalam situasi yang baru (Riyanto, 2009). Klien dengan skizofrenia mengalami defisit kognitif pada memori dan fungsi eksekutif pada tipe disorganized dimana tanda negatif lebih dominan dari pada tanda atau gejala positif fungsi eksekutif. Hal ini dapat terjadi karena pada gejala negatif menunjukkan ketidakmampuan dalam merencanakan dan mengorganisasi (Brazo et al, 2002).

Fungsi kognitif dapat dinilai dengan menggunakan berbagai pendekatan, meliputi : eksperimental, neuropsikologi dan psikometri, serta ekologi (Chan, 2005).Fungsi kognitif pada klien dengan skizofrenia terdiri dari fungsi atensi, memori, bahasa, dan eksekutif.

Fungsi atensi:Fungsi ini paling banyak ditemukan mengalami gangguan baik klien maupun pada keluarga dengan skizofrenia;

Fungsi memori:Kapasitas memori dipengaruhi oleh rangsangan baru dengan menggunakan metode yang abstrak dalam mencapai tujuan. Metode ini melibatkan analisis dan pengolahan informasi (Sharma,2003).Korteks prefrontal berperan pada memori kerja. Pada penelitian MRI (Diagnose brain tumor through MRI using image processing clustering algorithms such as Fuzzy C Means along with intelligent 
optimization techniques) yang dilakukan pada klien skizofrenia menunjukkan bahwa berkurangnya aliran darah dalam gyrus frontal bagian bawah (Gopal, 2005). Fungsi memori klien skizofrenia telah sering dinilai. Ingatan verbal, angka berulang, cerita, dan rancang geometris diketahui terganggu. Defisit ini seringkali jelas atau nyata tanpa memandang latar belakang gangguan intelektual umum (Tuulio-Henriksson, 2005).

Berbagai tahap dalam proses memori deklaratif (kejadian yang berhubungan, konteks spatiotemporal) berperan. Sejumah peneliti menemukan bahwa klien dengan skizofrenia memakai strategi encoding yang tidak efisien, sehingga mengabaikan regularitas semantik. Strategi retrieval yang tidak efisien dan usaha recall yang buruk juga ditemukan. Jika materi memori dinilai kembali setelah ditunda 20 menit atau lebih, klien dengan skizofrenia menunjukkan kecepatan melupakan yang ringan, hal ini bertolak belakang dengan klien amnestik yang cepat lupa. Kecepatan mempelajari item berdasarkan daftar juga diteliti. Klien dengan skizofrenia menunjukkan kemampuan mempelajari daftar namun dengan kecepatan yang lebih rendah dari subyek normal (Goldberg \& Gold, 2000).

\section{Fungsi bahasa}

Ranah bahasa merupakan perbedaan terbesar antara penilaian formal dan observasi klinis. Pembicaraan klien skizofrenia seringkali tidak logis, kacau, dan di luar realita, namun kadang juga memberikan nilai yang bagus ketika uji bahasa. Rausch dkk (2011) mengemukakan bahwa klien dengan skizofrenia menunjukkan fungsi yang hampir sama dengan kontrol normal ketika tes kemampuan menggunakan aturan linguistik. Dasar dari gangguan penggunaan bahasa pada klien skizofrenia mungkin secara teori dapat terjadi karena abnormalitas organisasi semantik.

Penelitian semantik membuktikan bahwa klien skizofrena menunjukkan waktu reaksi lebih lama untuk kata-kata yang dimaksud dengan dasar semantik dibandingkan subyek normal (contoh responss untuk 'kucing' lebih cepat bila didahului dengan kata 'anjing' dan bukan 'batu').

\section{Fungsi eksekutif}

Fungsi eksekutif meliputi beberapa kemampuan yaitu kemampuan memulai, mengurutkan, merencanakan, menyusun strategi pemecahan masalah, kemampuan berpikir abstrak, dan kemampuan berpindah secara fleksibel dari satu fungsi kognitif ke fungsi yang lainnya. Fungsi eksekutif banyak didukung oleh korteks frontalis, dimana berhubungan dengan bagian otak lain yang mempunyai hubungan erat dengan korteks frontalis, misalnya kompleks temporal limbik (Hoff \& Kremen, 2003). Klien skizofrenia menunjukkan karakteristik berkurangnya daya pikir abstrak dan kongkret.

\section{Indikasi LKS:}

Beberapa

penelitian menunjukkan bahwa LKSmerupakan salah satu intervensi dengan teknik modifikasi perilaku yang dapat diberikan pada klien dengan berbagai gangguan seperti depresi, skizofrenia, anak usia dini yang mengalami gangguan perilaku, kesulitan berinteraksi, klien yang mengalami fobia sosial dan klien yang mengalami kecemasan. Hal ini menunjukkan adanya hubungan bermakna dari pelaksanaan LKSdengan meningkatkan kemampuan klien dalam berinteraksi dengan orang lain diawali dengan melihat, mengobservasi, menirukan tingkah laku dan mempraktikkan dalam kehidupan seharihari (Bulkeley \& Cramer 1990, dalam Prawitasari, 2002) 


\section{Latihan Keterampilan Sosial}

Menurut Kneisl (2004) Latihan Keterampilan Sosial (LKS) merupakan metode yang berdasar pada beberapa prinsip sosial pembelajaran dan menggunakan teknik perilaku bermain peran, umpan balik dan praktik dalam meningkatkan kemampuan untuk menyelesaikan masalah. Stuart dan Laraia (2005) menyatakan bahwa LKS didasarkan pada keyakinan bahwa keterampilan dapat dipelajari bagi individu yang tidak memilikinya. LKS didasarkan pada keyakinan bahwa keterampilan dipelajari dan bisa diajarkan kepada mereka yang tidak memilikinya. Prinsip-prinsip keterampilan adalah sebagai berikut: bimbingan, demonstrasi, praktik dan umpan balik.

Prinsip-prinsip ini harus dimasukkan ke dalam penerapan yang efektif program LKS yang sering menjadi komponen dukungan pemulihan. Bimbingan dan demonstrasi biasanya digunakan pada awal perawatan, diikuti dengan latihan dan umpan balik. Perawatan biasanya mengikuti empat tahap: menggambarkan perilaku baru yang harus dipelajari, mempelajari perilaku yang baru melalui bimbingan dan demonstrasi, berlatih perilaku baru dengan umpan balik dan mempraktikkan perilaku yang baru ke kehidupan sehari - hari.

Jenis-jenis perilaku yang sering diajarkan dalam program-program ini termasuk mengajukan pertanyaan, memberi pujian, membuat perubahan positif, mempertahankan kontak mata, meminta orang lain untuk perubahan perilaku yang spesifik, berbicara dengan nada suara yang jelas, dan menghindari gelisah dan self-criticism. Strategi perawatan ini paling sering digunakan dengan klien yang tidak memiliki keterampilan sosial, ketegasan(pelatihan ketegasan), atau kontrol impuls, serta dengan klien yang menunjukkan perilaku anti sosial (Stuart, Gail W., 2013).

Tahapan terapi Latihan Keterampilan Sosialterbagi menjadi lima sesi yaitu :

1). Kemampuan berbicara dengan baik meliputi sikap tubuh yang baik, yang terdiri dari kontak mata yang dapat dipertahankan, tersenyum dan posisi tubuh tegak dan nyaman, mampu mengucapkan salam dan perkenalan dengan suara yang terdengar lawan bicara,mampu bertanya dan menjawab pertanyaan.

2) Kemampuan menjalin persahabatan.Meliputi kemampuan memberikan pujian kepada orang lain, meminta pertolongan bila membutuhkan, dan berani menawarkan bantuan untuk menolong orang lain.

3)Kemampuan bekerjasama dalam kelompok

Meliputi kemampuan memilih kegiatan yang akan dilakukan secara berkelompok, mampu membagi tugas dalam mneyelesaikan pekerjaan secara berkelompok, mampu memberi dan meminta pertolongan kepada teman atau orang lain dalam menyelesaikan kegiatan yang dipilih.

4) Kemampuan menghadapi situasi sulit Meliputi kemampuan mengungkapkan kritikan atau masukan kepada orang lain, berani menyampaikan penolakan kepada orang lain, mampu memberi maaf kepada orang lain, mampu berbicara menerima kritikan dari orang lain, mampu berbicara ketika mendapatkan penolakan dari orang lain, mampu meminta maaf kepada orang lain.

5) Kemampuan mengevaluasi manfaat bersosialisasi 
Mampu mengulangi kegiatan tahap demi tahap terapi secara mandiri dan dilakukan dalam kegiatan sehari hari sampai membudaya.

\section{Rasionalisasi dari Latihan Keterampilan Sosial untuk Skizofrenia.}

Latihan pemecahan masalah, keterampilan dan kompetensi sosial selain dapat digunakan untuk mencegah kekambuhan juga dapat digunakan dalam resiliensi, dukungan interpersonal, afiliasi sosial dan meningkatkan kualitas hidup. Efek protektif dari LKS yaitu membantu individu untuk menstabilkan kondisi mereka, meningkatkan untuk rutin berobat, perawatan secara psikososial dan meningkatkan tingkat kesembuhan (Salokangas, 2006).

Tabel 1. Rasionalisasi penggunaan LKS pada klien dengan skizofrenia

Masalah atau kebutuhan pribadi

Gejala positif yang persisten

Gejala negatif

Efek samping dari obat anti psikotik

hubungansosial

Manfaat dari latihan keterampilan untuk belajar

Keterampilan koping untuk mengelola gejala dan komunikasi interpersonal untuk melawan gejala psikotik pada terapi perilaku kognitif

Komunikasi verbal dan non verbal dan ekpres emosi

Keterampilan non verbal dan motor untuk melawan akinesia dan parkinsonisme

Langkah-langkah tambahan untukberkomunikasi dengan orang laindalam berbagai situasi;pemodelan dan permainan peran dalamsituasi pelatihan dapat mengurangi kecemasan

Emosional yang penuh tekanan di Peningkatan keterampilan verbal dan keluarga,dirumah atau pun di tempat non-verbal, asertif dari pada pasif atau kerja agresif, keterampilan pemecahan masalah sosial

Menurunnya fungsikognitif

Bekerja dan keterampilan pemecahan masalah sosial melalui prosedur dan pembelajaran aktif

Keterampilan penyakit;penggunaan andal;keterampilan denganpsikiater dan penyedia layanan lainnya; Pemberdayaandan harapan melalui keterampilan manajemen diri 
Isolasi sosial

Pekerjaan

Hidup mandiri
Konversasi yang baik, memiliki sahabat dapat menghilangkan isolasi sosial

Berkomunikasi dengan atasan dan rekan kerja

Pemecahan masalah dengan berkomunikasi terhadap orang lain
(Kopelowicz et al., 2006)

Penjelasan di atas mengenai rasionalisasi dari pelaksanaan LKS terdapat beberapa macam, salah satunya yaitu tentang menurunnya kognitif. Penjelasan yang didapatkan dari hal tersebut yaitu penggunaan otak seperti halnya dalam penggunaan otot, apabila digunakan secara terus-menerus maka fungsi otot akan terjaga. Seperti halnya otak apabila sering digunakan, maka akan terjaga pula fungsinya. Hal ini terlihat dalam sesi LKS yaitu berupa penghitungan dan pemecahan masalah pada situasi sulit. Keadaan seperti itulah fungsi otak dioptimalkan untuk mampu berhitung dan mencari solusi penyelesaianmasalah yang ada.

$$
\text { Penelitian lain yang }
$$

menunjukkan bahwa LKS dapat mempengaruhi fungsi otak pada orang dewasa dengan gangguan kognitif. Penelitian dari Harisson yang berjudul The Effects Of Social Skill Training In A Simulated Community Environment For Adolescents With Cognitive Impairments bertujuan untuk mengevaluasi dampak dari pemberian instruksi keterampilan sosial berdasarkan kemampuan sosial siswa di sekolah. Penelitian ini menunjukkan peningkatan pada beberapa item penilaian seperti halnya kontak mata, perbincangan, tingkah laku dan minta bantuan. Hal ini berarti bahwa mengindikasikan individu berlatih keterampilan sosial melalui pemodelan guru dan instruksi langsung dapat belajar dan mampu menghadirkan keterampilan sosial yang tepat (Harrison, Xin, \& Ed, 2016).

Tabel literature review.

\begin{tabular}{|c|c|c|c|c|c|c|}
\hline No & Penulis & Judul & Desain & Responden & $\begin{array}{l}\text { Prosedur } \\
\text { Penilaian }\end{array}$ & Hasil \\
\hline 1. & $\begin{array}{l}\text { Glenthoj } \\
\text { et. Al } \\
(2016)\end{array}$ & $\begin{array}{l}\text { Social } \\
\text { cognition in } \\
\text { patients at } \\
\text { ultra high risk } \\
\text { for psychosis: } \\
\text { What is the } \\
\text { relation to } \\
\text { social skills } \\
\text { and } \\
\text { functioning? }\end{array}$ & $\begin{array}{l}\text { Penelitian } \\
\text { kuantitatif }\end{array}$ & \begin{tabular}{lr} 
Penelitian & \\
melibatkan & 65 \\
\multicolumn{2}{l}{ pasien dengan risiko } \\
tinggi psychosis & dan \\
kontrol & 30 \\
responden &
\end{tabular} & $\begin{array}{l}\text { Penelitian } \\
\text { meliputi } \\
\text { fungsi } \\
\text { kognitif } \\
\text { sosial, } \\
\text { keterampilan } \\
\text { sosial dan } \\
\text { pengukuran } \\
\text { fungsi } \\
\text { lainnya. }\end{array}$ & $\begin{array}{l}\text { Gangguan } \\
\text { yang signifikan } \\
\text { pada kognitif } \\
\text { sosial dan } \\
\text { keterampilan } \\
\text { sosial } \\
\text { ditemukan } \\
\text { pada klien } \\
\text { dengan risiko } \\
\text { tinggi. Fungsi } \\
\text { kognitif sosial } \\
\text { klien } \\
\text { berhubungan }\end{array}$ \\
\hline
\end{tabular}




\begin{tabular}{|c|c|c|c|c|c|c|}
\hline & & & & & & $\begin{array}{l}\text { dengan } \\
\text { keterampilan } \\
\text { sosial }\end{array}$ \\
\hline 2. & $\begin{array}{l}\text { Renidayati } \\
(2008)\end{array}$ & $\begin{array}{l}\text { Pengaruh } \\
\text { Social Skill } \\
\text { Training } \\
\text { (SST) Pada } \\
\text { Klien Isolasi } \\
\text { Sosial di } \\
\text { Rumah Sakit } \\
\text { Jiwa Prof. } \\
\text { HB. Saanin } \\
\text { Padang, } \\
\text { Sumatera } \\
\text { Barat. }\end{array}$ & $\begin{array}{l}\text { Penelitian } \\
\text { kuantitatif }\end{array}$ & $\begin{array}{l}\text { Penelitianmelibatka } \\
\text { n } 60 \text { responden, } \\
\text { dimana } 30 \\
\text { respondenuntukkelo } \\
\text { mpokintervensidan } \\
30 \\
\text { respondenuntukkelo } \\
\text { mpokkontrol }\end{array}$ & $\begin{array}{l}\text { Sebelum dan } \\
\text { sesudah } \\
\text { terapi SST } \\
\text { diberikan pre } \\
\text { dan post } \\
\text { mengenai } \\
\text { kemampuan } \\
\text { kognitif dan } \\
\text { kemampuan } \\
\text { perilaku. }\end{array}$ & $\begin{array}{l}\text { Terdapat } \\
\text { peningkatan } \\
\text { kemampuan } \\
\text { kognitif dan } \\
\text { perilaku pada } \\
\text { responden yang } \\
\text { diberikan SST. }\end{array}$ \\
\hline 3. & $\begin{array}{l}\text { Jessica } \\
\text { Harrison } \\
(2016)\end{array}$ & $\begin{array}{l}\text { The Effects of } \\
\text { Social Skill } \\
\text { Training } \\
\text { (SST) In A } \\
\text { Simulated } \\
\text { Community } \\
\text { Environment } \\
\text { For } \\
\text { Adolescents } \\
\text { With } \\
\text { Cognitive } \\
\text { Impairements. }\end{array}$ & $\begin{array}{l}\text { Penelitian } \\
\text { kuantitatif. }\end{array}$ & $\begin{array}{l}\text { Tiga responden usia } \\
15-16 \text { tahun. }\end{array}$ & $\begin{array}{l}\text { Observasi } \\
\text { dilakukan } \\
\text { pada sebelum } \\
\text { dan sesudah } \\
\text { SST } \\
\text { diberikan. }\end{array}$ & $\begin{array}{l}\text { Penelitian ini } \\
\text { menunjukkan } \\
\text { bahwa SST } \\
\text { untuk Cognitive } \\
\text { Impairements } \\
\text { dengan } \\
\text { simulasi efektif } \\
\text { untuk } \\
\text { memperolah } \\
\text { keterampilan } \\
\text { sosial. Hal ini } \\
\text { mengindikasika } \\
\text { n bahwa SST } \\
\text { melalui model } \\
\text { instruksi dan } \\
\text { pembelajaran } \\
\text { menghasilkan } \\
\text { pembelajaran } \\
\text { yang lebih baik } \\
\text { dan } \\
\text { memperoleh } \\
\text { keterampilan } \\
\text { sosial yang } \\
\text { sesuai. }\end{array}$ \\
\hline 4. & $\begin{array}{l}\text { Van Der } \\
\text { Stouwe et. } \\
\text { al. }(2018)\end{array}$ & $\begin{array}{l}\text { Social Skill } \\
\text { Training } \\
\text { (SST) effects } \\
\text { on Social } \\
\text { Information } \\
\text { Processing } \\
\text { Skills In } \\
\text { Justice- } \\
\text { Involved } \\
\end{array}$ & $\begin{array}{l}\text { Penelitian } \\
\text { Kuantitatif }\end{array}$ & \begin{tabular}{lr}
\multicolumn{2}{l}{ Kelompok } \\
intervensi & terdiri \\
dari 115 & responden \\
dan & kelompok \\
kontrol & 108 \\
responden. &
\end{tabular} & $\begin{array}{l}\text { Para remaja } \\
\text { dalam } \\
\text { kelompok } \\
\text { intervensi } \\
\text { menerima } \\
\text { Tools4U } \\
\text { mendapatkan } \\
\text { terapi SST. } \\
\text { Sedangkan } \\
\end{array}$ & $\begin{array}{l}\text { Intervensi } \\
\text { yang diberikan } \\
\text { memberikan } \\
\text { bukti bahwa } \\
\text { hal tersebut } \\
\text { efektif dalam } \\
\text { mengurangi } \\
\text { distorsi } \\
\text { kognitif }\end{array}$ \\
\hline
\end{tabular}




\begin{tabular}{|c|c|c|c|c|c|c|}
\hline & & $\begin{array}{l}\text { Adolescents: } \\
\text { Affective } \\
\text { Empathy as } \\
\text { Predictor or } \\
\text { Moderator }\end{array}$ & & & $\begin{array}{l}\text { pada } \\
\text { kelompok } \\
\text { kontrol } \\
\text { mendapatkan } \\
\text { perawatan } \\
\text { seperti } \\
\text { biasanya. }\end{array}$ & $\begin{array}{l}\text { (seperti halnya } \\
\text { egois, } \\
\text { berasumsi } \\
\text { buruk/ } \\
\text { negativ). }\end{array}$ \\
\hline 5. & \begin{tabular}{l}
\multicolumn{2}{l}{ Luckhordt } \\
et. al. \\
$(2018)$
\end{tabular} & $\begin{array}{l}\text { Facilitation of } \\
\text { Biological } \\
\text { Motion } \\
\text { Processing by } \\
\text { Group-Based } \\
\text { Autism } \\
\text { Specific Social } \\
\text { Skill Training } \\
\text { (SST) }\end{array}$ & $\begin{array}{l}\text { Penelitian } \\
\text { Kuantitatif. }\end{array}$ & $\begin{array}{l}\text { Anak dan remaja } \\
\text { yang berusia } 8-20 \\
\text { tahun dengan } \\
\text { Autism Spectrum } \\
\text { Disorder) }\end{array}$ & $\begin{array}{l}\text { Kelompok } \\
\text { intervensi } \\
\text { yang terdiri } \\
\text { dari anak- } \\
\text { anak dan } \\
\text { remaja } \\
\text { mendapatkan } \\
\text { terapi SST. }\end{array}$ & $\begin{array}{l}\text { Intervensi SST } \\
\text { dapat } \\
\text { membantu } \\
\text { klien ASD } \\
\text { meningkatkan } \\
\text { perilakunya. } \\
\text { Hal ini } \\
\text { menunjukkan } \\
\text { bahwa terapi } \\
\text { dapat } \\
\text { mengubah } \\
\text { proses sosial di } \\
\text { otak (syaraf } \\
\text { yang } \\
\text { berhubungan } \\
\text { dengan } \\
\text { persepsi sosial } \\
\text { di ASD). } \\
\text { Persepsi } \\
\text { tersebut sangat } \\
\text { berperan dalam } \\
\text { keberhasilan } \\
\text { interaksi sosial. }\end{array}$ \\
\hline 6. & $\begin{array}{l}\text { Kopalowics } \\
\text { et. al. } \\
(2006)\end{array}$ & $\begin{array}{l}\text { Recent } \\
\text { Advances In } \\
\text { Social Skills } \\
\text { Training } \\
\text { (SST) for } \\
\text { Schizophrenia. }\end{array}$ & Buletin & - & - & $\begin{array}{l}\text { Terdapat } \\
\text { hubungan } \\
\text { padafungsikog } \\
\text { nitif yaitu } \\
\text { keterampilan } \\
\text { memecahkan } \\
\text { masalah } \\
\text { melalui } \\
\text { prosedur dan } \\
\text { aktif } \\
\text { pembelajaran. }\end{array}$ \\
\hline & $\begin{array}{l}\text { Simpulan } \\
\qquad \text { LKS } \\
\text { sebagian } \\
\text { meningkatk } \\
\text { keterampila } \\
\text { Hal ini }\end{array}$ & $\begin{array}{l}\text { merupakan inte } \\
\text { besar ditujuk } \\
\text { in komunik } \\
\text { baru dalam } \mathrm{f} \\
\text { iasanya dilakı }\end{array}$ & $\begin{array}{lr} & \\
& \\
& \\
n & \text { untuki } \\
\text { n yang } \\
\text { si } & \text { dan } \\
\text { ngsi } & \text { sosial. } \\
\text { kan } & \text { pada }\end{array}$ & $\begin{array}{l}\text { skizofrenia } \\
\text { Penelitian lair } \\
\text { LKS juga da } \\
\text { yang sehat, } \\
\text { pada anak-a } \\
\text { keterampilan } \\
\text { dampak pada }\end{array}$ & $\begin{array}{l}\text { gan isolasi } \\
\text { menunjukkan } \\
\text { diberikan pad } \\
\text { erti halnya di } \\
\text { untuk menc } \\
\text { u. LKS juga n } \\
\text { agsi kognitif in }\end{array}$ & $\begin{array}{l}\text { sosial. } \\
\text { bahwa } \\
\text { a klien } \\
\text { berikan } \\
\text { ptakan } \\
\text { emiliki } \\
\text { dividu. }\end{array}$ \\
\hline
\end{tabular}


Dampak tersebut terlihat pada sesi yang terdapat dalam LKS berupa penghitungan dan simulasi pemecahan masalah pada situasi sulit. Hal ini juga terbukti bahwa LKS dapat memberikan dampak positif pada klien dengan gangguan kognitif.

Sedikitnya penelitian yang membahas tentang fungsi kognitif dalam LKS memberikan rujukan yang sedikit pula. Diharapkan dapat muncul penelitian-penelitian lainnya yang lebih banyak yang membahas tentang dampak LKS terhadap fungsi kognitif. Selain itu, diharapkan juga banyak dilakukannya intervensi LKS pada klien dengan berbagai kondisi yang memerlukan keterampilan baru untuk menunjang kemandirian dari klien tersebut. Sehingga manfaatnya akan lebih terlihat apabila sering digunakan.

\section{Daftar pustaka}

Arsova, S., Bajraktarov, S., Barbov, I.,

Hadzihamza, K. 2014. Patients with

Schizophrenia and Self-Care.

Macedonia Journal of Medical

Science, volume: 7, 291-294.

Azizah, F. N., Hamid, A. Y. S., \&

Wardani, I. Y. (2017). Respons

Sosial dan Kemampuan Sosialisasi

Pasien Isolasi Sosial Melalui

Manajemen Kasus Spesialis

Keperawatan Jiwa. Media Ilmu

Kesehatan, Volume 6(No. 2), 91-100.

Bhatti, A. B., \& Haq, A. ul. (2017). The

Pathophysiology of Perceived Social

Isolation: Effects on Health and

Mortality. Cureus, 9(1), 1-10.

https://doi.org/10.7759/cureus.994

Biordi, D. L., \& Nicholson, N. R. (2013).

Social Isolation. Chronic Illness:

Impact And Intervention, 85-115.

https://doi.org/10.1111/j.1749-

6632.2011.06028.x.Social
Bosworth, H. B., \& Ayotte, B. J. (2009). The role of cognitive and social function in an applied setting: Medication adherence as an example. In H. B. Bosworth \& C. Hertzog (Eds.), Aging and Cognition: Research Methodologies and Empirical Advances (pp. 219-239). Washington, DC: American Psychological Association.

Bulkeley, R, and cramer, D. (1990). Social skills training with young adolescent, Journal of youth and adolecence, 19 (5), 451-463.

Dahar, Ratna Wilis, (2011), Teori-teori Belajar \& Pembelajaran, Erlangga, Jakarta

Goldberg S. \& Gold J.M., 2000. Neurocognitive Function in

Schizophrenia, in

Neuropsychopharmacology: The Fifth Generation of Progress, available at www.neuropsychopharmacology.co m.

Harrison, J., Xin, T. J. F., \& Ed, D. (2016). The Effects Of Social Skill Training In A Simulated Community Environment For Adolescents With Cognitive by Submitted to the Department of Interdisciplinary and Inclusive Education College of Education In partial fulfillment of the requirement For the degree of Master of Arts in Learning Disabilities at Rowan University.

Hergenhahn, B.R dan Olson, Matthew H.(2010). Theories of Learning. Jakarta: Kencana PRenada Media Group. Jakarta.

Hoff A.L., \& Kremen W.S., (2003). Neuropsychology in Schizophrenia : An Update,Current Opinion in Psychiatry. 
Hultsch DF, Hertzog C, Small BJ, Dixon RA. (1999) Use it or lose it:engaged lifestyle as a buffer of cognitive decline in aging? Psychol Aging;14:245.

Jurado, M. B., \& Rosselli, M. (2007). The elusive nature of executive functions: A review of our current understanding. Neuropsychology Review, 17, 213-233.

Kneisl,C.R. et.al. (2004). Contemporary Psychiatric Mental Health Nursing. New Jersey: Prentice Hall New Jersey.

Kopelowicz, A., Liberman, R. P., \& Zarate, R. (2006). Recent advances in social skills training for schizophrenia. In Schizophrenia Bulletin. https://doi.org/10.1093/schbul/sbl02 3

Manoach, D. S. (2010). Cognitive Deficits in Schizophrenia. Encyclopedia of Neuroscience, 1101-1109. https://doi.org/10.1016/B978008045046-9.00425-3

Matlin, M. W. (2003). Cognition (5th ed.). Hoboken: John Wiley \& Sons, Inc.

Modi, A.C., Rausch, J.R., \& Glauser, T.A.(2011), Patterns of nonadherence to antiepileptic drug therapy in children with newly diagnosed epilepsy, JAMA, 305

Peplau, L.A., Perlman, D. (1982). Loneliness: A Source Book of Current, Theory, Research and Therapy. Toronto: John Wiley \&
Sons. Inc.

Prawitasari, J.E., Rochman, M, . Ramdhani, N dan Utami, M.S. (2002). Psikoterapi: Pendekatan konvensional dan kontemporer, Yogyakarta: Pustaka pelajar offset.

Reed, S. K. (2012). Cognition: Theories and Appilcations (9th ed.). Belmont, CA: Jon-Daavid Hague.

Salokangas RKR, Honkonen T, Stengard E, Koivisto AM., 2006, Subjective life satisfaction and living situations of persons in Finland with long-term schizophrenia. Psychiatr Serv.;57:373-381.

Sanjaya, Wina. (2010). Strategi Pembelajaran Berorientasi Standar Proses Pendidikan. Jakarta : Prenada Media Group

Sells, S. B. (2008). The taxonomy of man in enclosed space. In J. Rasmussen (Ed.), Man in isolation and confinement (pp. 281-304). New Brunswick, NJ: Aldine Transaction.

Stuart, Gail W., et. al. (2013). Principles and Practice of Psychiatric Nursing (10th editi). Missoury: Mosby.

Tuulio-Henriksson A., 2005. Cognitive Dysfunction in Schizophrenia : A Familial and Genetic Approach, Department of Psychology and Department of Psychiatry, University of Helsinki. Dissertation

Varcarolis, E.M., Carson, V.B. \& Shoemaker, N.C., 2006, Foundations of Psychiatric Mental

Health Nursing, 5th Edition, Saunders Elsevier, USA. 